\title{
NOTICES
}

The International Commission on Zoological Nomenclature has received the following applications; comment or advice on them would be welcomed, and comments would be published in the Bulletin of Zoological Nomenclature.

Case no. 2579 (Bulletin of Zoological Nomenclature 44 (1), 23 March 1987). Desorella Cotteau, 1855 (Echinodermata, Echinoidea): proposed confirmation of Hyboclypus elatus Desor, 1847 as type species.

Case no. 2455 (Bulletin of Zoological Nomenclature 44 (2), 25 June 1987). Chagrinichnites brooksi Feldmann, Osgood, Szmuc \& Meinke, 1978 and Chagrinichnites osgoodi Hannibal \& Feldmann, 1983 (Trace fossils): proposed conservation.

Case no. 2569 (Bulletin of Zoological Nomenclature 44 (2), 25 June 1987). Halianassa studeri von Meyer, 1838 (Mammalia, Sirenia): proposed designation of a neotype, and proposed conservation of Halitherium Kaup, 1838 by designation of type species.

The following Opinions have been published recently by the International Commission on Zoological Nomenclature, c/o British Museum (Natural History), Cromwell Road, London SW7 5BD, U.K.

Opinion no. 1429 (Bulletin of Zoological Nomenclature 44 (1), 23 March 1987).

A ruling on the authorship and dates of the Sowerbys' Mineral Conchology of Great Britain.

Opinion no. 1433 (Bulletin of Zoological Nomenclature 44 (2), 25 June 1987)

Calymene Brongniart in Brongniart \& Desmarest, 1822 (Trilobita): conserved.

Opinion no. 1434 (Bulletin of Zoological Nomenclature $\mathbf{4 4}$ (2), 25 June 1987).

Cyphaspis Burmeister, 1843 (Trilobita): Phacops ceratophthalmus Goldfuss 1843, designated as type species.

Opinion no. 1435 (Bulletin of Zoological Nomenclature 44 (2), 25 June 1987).

Cheirurus Beyrich, 1845 (Trilobita): Cheirurus insignis Beyrich, 1845 designated as type species.

Opinion no. 1436 (Bulletin of Zoological Nomenclature 44 (2), 25 June 1987).

Harpidae Hawle \& Corda, 1847 (Trilobita) and Harpidae Bronn, 1849 (Mollusca, Gastropoda): a ruling to remove the homonymy.

The Commission regrets that it cannot supply separates of Opinions.

\section{Official Lists and Indexes of names and works in Zoology}

A revised and updated edition of the Official Lists and Indexes of names and works in Zoology has now been published. For the first time all the names and works on which the International Commission on Zoological Nomenclature has ruled since it was set up in 1895 are brought together in a single volume. Entries are arranged in four sections giving in alphabetical order the family-group names, generic names, specific names and titles of works which have been placed on the Official Lists or the Official Indexes. There are about 9900 entries of which 134 are for works. In addition, there is a full systematic index and a reference list to all relevant Opinions and Directions. The volume is 366 pages, size A4, casebound.

Copies can be ordered from:

The International Trust for Zoological Nomenclature, $\mathrm{c} / \mathrm{o}$ British Museum (Natural History), Cromwell Road, London SW7 5BD, U.K. Price $£ 60$ or $\$ 110$

or

The American Association for Zoological Nomenclature, c/o NHB Stop 163, National Museum of Natural History, Washington D.C. 20560, U.S.A. Price $\$ 110$ (\$100 to members of A.A.Z.N.)

\section{Call for nominations for new members of the International} Commission on Zoological Nomenclature.

The following members of the Commission reach the end of their terms of service at the close of the XXIII General Assembly of the International Union of Biological Sciences to be held in Canberra in October 1988: Prof. Dr R. Alvarado (Spain; specialist field Echinodermata); Dr G. Bernardi (France; Lepidoptera); Prof C. Dupuis (France; Heteroptera) and Dr L. B. Holthuis (The Netherlands; Crustacea). A further vacancy arises from the death of Prof B. S. Zheng (People's Republic of China; Ichthyology).

The addresses and specialist fields of the present members of the Commission may be found in the Bulletin of Zoological Nomenclature 44 (1), pp. 2-3 (March 1987). Under Article $3 b$ of the Commission's Constitution a member whose term of service has terminated is not eligible for immediate reelection unless the Council of the Commission has decided to the contrary.

The Commission now invites nominations, by any person or institution, of candidates for membership. Article $2 b$ of the Constitution prescribes that: 'The members of the Commission shall be eminent scientists, irrespective of nationality, with a distinguished record in any branch of zoology, who are known to have an interest in zoological nomenclature'. (It should be noted that 'zoology' here includes the applied biological sciences (medicine, agriculture, etc.), which use zoological names.)

Nominations, giving the dates of birth, nationality and qualifications (by the criteria mentioned above) of each candidate should be sent by 31 March 1988 to: The Executive Secretary, International Commission on Zoological Nomenclature, c/o British Museum (Natural History), Cromwell Road, London, SW7 5BD, U.K. 